\title{
Characterization of peri-infarct zone by CMR is a robust predictor of major adverse events and is strongly associated with systemic inflammatory response post-myocardial infarction
}

\author{
Andrei Sposito ${ }^{1}$, Otavio R Coelho-Filho ${ }^{2 *}$, Joalbo M Andrade ${ }^{3}$, Ana Laura R Araújo ${ }^{3}$, Dulcineia SP Abdalla ${ }^{3}$, \\ Eliana Cotta Faria', Rob J van der Geest ${ }^{4}$, Jose C Quinaglia Silva ${ }^{3}$, Otavio R Coelho ${ }^{1}$, Jose AF Ramires ${ }^{5}$, \\ Michael Jerosch-Herold ${ }^{2}$, Raymond Y Kwong ${ }^{2}$
}

From 2011 SCMR/Euro CMR Joint Scientific Sessions

Nice, France. 3-6 February 2011

\section{Introduction}

While previous studies suggest that the peri-infarct zone (PIZ) may be an important arrhythmogenic substrate and may be associated with an unfavorable outcome post-MI, to date, there is no convincing mechanistic explanation to support that relationship. Systemic inflammatory response (SIR) in the acute phase post-MI has also been associated an adverse prognosis.Furthermore, a strong SIR may lead to greater heterogeneity of the infarcted myocardium. We hypothesized that the PIZ extent would be associated with the severity of the post-MI SIR. We further sought to determine if prognostic information provided by PIZ extent and SIR would complement classical markers of adverse outcome post-MI.

\section{Method/results}

We prospectively enrolled 102 patients (24 females, mean age $55 \pm 10$ ) admitted with a ST elevation MI. SIR was estimated on admission (D1) and on the $5^{\text {th }}$ postMI day (D5) by levels of high-sensitivity CRP, interleukin-2 (IL-2) and tumor necrosis factor type- $\alpha$ (TNF- $\alpha$ ). CMR was performed 4-weeks after MI(1.5-TGE-CV/i) including cine imaging, and LGE 10-minutes after a cumulative dose of $0.2 \mathrm{mmol} / \mathrm{Kg}$ of gadolinium. PIZ, total and core infarct mass were quantified based on signal-intensity (SI) thresholds using the full-width at halfmaximum method (tissue with SI>peak remote but $<50 \%$

'Brigham and Women's Hospital, Boston, MA, USA

Full list of author information is available at the end of the article of max was defined as PIZ). At a median follow-up of 16.1 months (IQR12.3), 25 major adverse cardiovascular events (MACE)(24\%) had occurred (11 cardiac deaths, 8 MIs and 6 unstable anginas). CRP, IL- 2 and TNF- $\alpha$ measured at D5 and the variation between D1 and D5 (delta) demonstrated a strong association with PIZ (CRP-D5, $\mathrm{r}=0.69, \mathrm{p}<0.0001$; delta-CRP, $\mathrm{r}=0.7, \mathrm{p}<0.0001$; IL-2-D5, $\mathrm{r}=0.5, \mathrm{p}<0.0001$; delta-IL-2, $\mathrm{r}=0.6, \mathrm{p}<0.0001$; TNF- $\alpha, r=0.5, p<0.0001$; delta-TNF- $\alpha, r=0.4, p=0.0001$ ). After adjustment for age, total infarct size, gender and for their respective baseline level, delta-CRP, delta-IL-2 and delta-TNF- $\alpha$ maintain strong association with the PIZ mass expressed as tertiles (delta-CRP, $\mathrm{R}^{2}=0.5$, $\mathrm{p}<0.0001$; delta-IL-2, $\mathrm{R}^{2}=0.3, \mathrm{p}=0.02$; delta-TNF- $\alpha$, $\left.\mathrm{R}^{2}=0.5, \mathrm{p}=0.003\right)$. By univariable analysis, the PIZ mass, total infarct size, delta-CRP and delta-IL2 showed the strongest association with MACE(PIZ, LR $\chi^{2}$ 25.7, HR

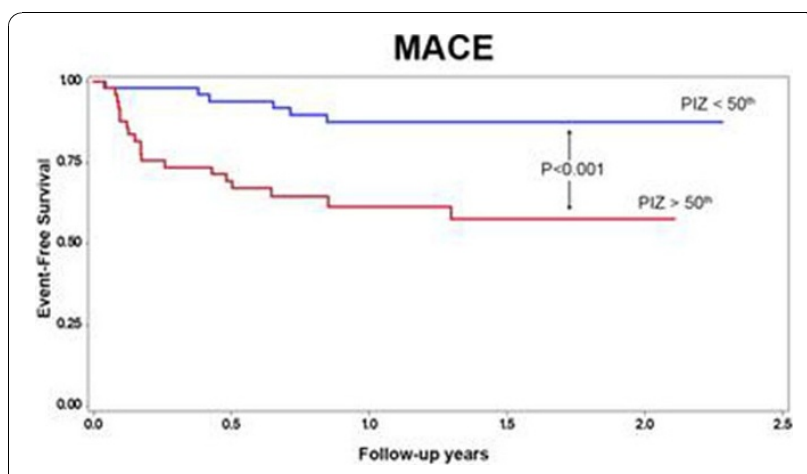

Figure 1

(C) 2011 Sposito et al; licensee BioMed Central Ltd. This is an open access article distributed under the terms of the Creative Commons 
1.13, $\mathrm{P}<0.0001$; total infarct mass, $\mathrm{LR} \chi^{2} 7.2$, HR 1.03, $\mathrm{P}=0.006$; delta-CRP, $\mathrm{LR} \chi^{2} 25.3$, HR 1.15, $\mathrm{P}<0.0001$; delta-IL2, $\mathrm{LR} \chi^{2} 19.3$, HR 1.08, $\left.\mathrm{P}<0.0001\right)$. After adjustment for age, LVEF and delta-CRP, PIZ mass maintained a strong adjusted association with MACE (adjusted $\mathrm{LR} \chi^{2}$ 8.5, HR 1.17, $\mathrm{P}=0.003$ ). Patients with PIZ mass $>50^{\text {th }}$ demonstrated a significantly reduced MACEfree survival $(\mathrm{p}=0.0008$, Figure 1$)$

\section{Conclusion}

PIZ as evidence of infarct tissue heterogeneity provides prognostic information post-MI. In addition, the extent of PIZ by CMR is strongly associated with SIR in the subacute phase post-MI.

\section{Author details}

${ }^{1}$ Faculty of Medical Sciences, State University of Campinas (Unicamp),

Campinas, Brazil. 'Brigham and Women's Hospital, Boston, MA, USA.

${ }^{3}$ University of Brasilia (UnB), Brasilia, Brazil. ${ }^{4}$ Leiden University Medical Center,

The Netherlands, Leiden, Netherlands. ${ }^{5}$ Heart Institute (InCor), University of

Sao Paulo, Sao Paulo, Brazil.

Published: 2 February 2011

Cite this article as: Sposito et al:: Characterization of peri-infarct zone by

CMR is a robust predictor of major adverse events and is strongly associated with systemic inflammatory response post-myocardial infarction. Journal of Cardiovascular Magnetic Resonance 2011 13(Suppl 1): P180.

Submit your next manuscript to BioMed Central and take full advantage of:

- Convenient online submission

- Thorough peer review

- No space constraints or color figure charges

- Immediate publication on acceptance

- Inclusion in PubMed, CAS, Scopus and Google Scholar

- Research which is freely available for redistribution

Submit your manuscript at www.biomedcentral.com/submit
C Biomed Central 